\title{
Front Matter: Volume 8084
}

, "Front Matter: Volume 8084," Proc. SPIE 8084, O3A: Optics for Arts, Architecture, and Archaeology III, 808401 (8 July 2011); doi:

10.1117/12.902861

SPIE. Event: SPIE Optical Metrology, 2011, Munich, Germany 


\section{PROCEEDINGS OF SPIE}

\section{O3A: Optics for Arts, Architecture, and Archaeology III}

Luca Pezzati

Renzo Salimbeni

Editors

25-26 May 2011

Munich, Germany

Sponsored and Published by

SPIE 
The papers included in this volume were part of the technical conference cited on the cover and title page. Papers were selected and subject to review by the editors and conference program committee. Some conference presentations may not be available for publication. The papers published in these proceedings reflect the work and thoughts of the authors and are published herein as submitted. The publisher is not responsible for the validity of the information or for any outcomes resulting from reliance thereon.

Please use the following format to cite material from this book:

Author(s), "Title of Paper," in O3A: Optics for Arts, Architecture, and Archaeology III, edited by Luca Pezzati, Renzo Salimbeni, Proceedings of SPIE Vol. 8084 (SPIE, Bellingham, WA, 2011) Article CID Number.

ISSN 0277-786X

ISBN 9780819486806

Published by

SPIE

P.O. Box 10, Bellingham, Washington 98227-0010 USA

Telephone +1 3606763290 (Pacific Time) · Fax +1 3606471445

SPIE.org

Copyright (C) 2011, Society of Photo-Optical Instrumentation Engineers

Copying of material in this book for internal or personal use, or for the internal or personal use of specific clients, beyond the fair use provisions granted by the U.S. Copyright Law is authorized by SPIE subject to payment of copying fees. The Transactional Reporting Service base fee for this volume is $\$ 18.00$ per article (or portion thereof), which should be paid directly to the Copyright Clearance Center (CCC), 222 Rosewood Drive, Danvers, MA 01923. Payment may also be made electronically through CCC Online at copyright.com. Other copying for republication, resale, advertising or promotion, or any form of systematic or multiple reproduction of any material in this book is prohibited except with permission in writing from the publisher. The CCC fee code is 0277-786X/11/ \$18.00.

Printed in the United States of America.

Publication of record for individual papers is online in the SPIE Digital Library.

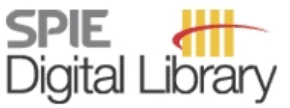

SPIEDigitalLibrary.org

Paper Numbering: Proceedings of SPIE follow an e-First publication model, with papers published first online and then in print and on CD-ROM. Papers are published as they are submitted and meet publication criteria. A unique, consistent, permanent citation identifier (CID) number is assigned to each article at the time of the first publication. Utilization of CIDs allows articles to be fully citable as soon as they are published online, and connects the same identifier to all online, print, and electronic versions of the publication. SPIE uses a six-digit CID article numbering system in which:

- The first four digits correspond to the SPIE volume number.

- The last two digits indicate publication order within the volume using a Base 36 numbering system employing both numerals and letters. These two-number sets start with 00, 01, 02, 03, 04, $05,06,07,08,09,0 A, 0 B \ldots 0 Z$, followed by 10-1Z, 20-2Z, etc.

The CID number appears on each page of the manuscript. The complete citation is used on the first page, and an abbreviated version on subsequent pages. Numbers in the index correspond to the last two digits of the six-digit CID number. 


\section{Contents}

vii Conference Committee

KEYNOTE SESSION

808402 A nuclear-free land for Kennewick Man [8084-01]

J. Asmus, Univ. of California, San Diego (United States)

IMAGING AND SPECTRAL METHODS I

808403 New portable instrument for combined reflectance, time-resolved and steady-state luminescence measurements on works of art (Invited Paper) [8084-02]

A. Romani, Ctr. SMAart, Univ. di Perugia (Italy); C. Grazia, Univ. di Perugia (Italy); C. Anselmi, Ctr. SMAart, Univ. di Perugia (Italy); C. Miliani, Ctr. SMAart, Univ. di Perugia (Italy) and CNR-ISTM, Univ. di Perugia (Italy); B. G. Brunetti, Ctr. SMAart, Univ. di Perugia (Italy)

808405 Autofocus laser system for multi-NIR scanning imaging of painting surfaces [8084-04] R. Fontana, M. Barucci, P. Carcagni, C. Daffara, E. Pampaloni, L. Pezzati, Istituto Nazionale di Ottica, CNR (Italy)

IMAGING AND SPECTRAL METHODS II

808406 Wide-band IR imaging in the NIR-MIR-FIR regions for in situ analysis of frescoes (Invited Paper) [8084-05]

C. Daffara, L. Pezzati, Istituto Nazionale di Ottica, CNR (Italy); D. Ambrosini, D. Paoletti,

R. Di Biase, Univ. dell' Aquila (Italy); P. I. Mariotti, C. Frosinini, Opificio delle Pietre Dure (Italy)

808407 New trends in imaging spectroscopy: the non-invasive study of the Scrovegni Chapel stained glass windows [8084-06]

E. Rebollo, Univ. degli Studi di Padova (Italy) and Consorzio Interuniversitario Nazionale per la Scienza e Tecnologia dei Materiali (Italy); F. Ratti, Istituto di Fotonica e Nanotecnologie, CNR (Italy); G. M. Cortelazzo, Univ. degli Studi di Padova (Italy); L. Poletto, Istituto di Fotonica e Nanotecnologie, CNR (Italy); R. Bertoncello, Univ. degli Studi di Padova (Italy) and Consorzio Interuniversitario Nazionale per la Scienza e Tecnologia dei Materiali (Italy)

808408 Open issues in hyperspectral imaging for diagnostics on paintings: when high-spectral and spatial resolution turns into data redundancy [8084-07]

C. Cucci, A. Casini, M. Picollo, M. Poggesi, L. Stefani, Istituto di Fisica Applicata Nello

Carrara, CNR (Italy) 
IMAGING AND SPECTRAL METHODS III

808409 Terahertz pulse imaging of stratified architectural materials for cultural heritage studies [8084-08]

J. B. Jackson, Ecole Polytechnique-ParisTech (France) and Lab. du Centre de Recherche et de Restauration des Musées de France, CNRS, Palais du Louvre (France); J. Labaune,

G. Mourou, Ecole Polytechnique-ParisTech (France); I. N. Duling, Picometrix-API, Inc. (United

States); G. Walker, J. Bowen, The Univ. of Reading (United Kingdom); M. Menu, Lab. du

Centre de Recherche et de Restauration des Musées de France, CNRS, Palais du Louvre

(France)

\section{DATA PROCESSING}

$8084 \mathrm{OB}$ Virtual restoration: detection and removal of craquelure in digitized image of old paintings [8084-10]

G. Schirripa Spagnolo, Univ. degli Studi di Roma Tre (Italy)

8084 OC Development of a UV to IR extension to the standard colorimetry, based on a seven band modified DSLR camera to better characterize surfaces, tissues and fabrics [8084-11]

M. Melis, Profilocolore Srl (Italy); A. Babbi, Univ. degli Studi di Roma Tor Vergata (Italy);

M. Miccoli, Univ. degli Studi di Roma La Sapienza (Italy)

8084 OD Determination of the complex optical index of red pigments, vermillon [8084-12]

R. Jarrige, C. Andraud, J. Lafait, Univ. Pierre et Marie Curie (France); M. Eveno, M. Menu, Ctr. de Recherche et de Restauration des Musées de France, CNRS, Palais du Louvre (France);

N. Diniz, Glaizer Group (France)

\section{TOMOGRAPHY}

8084 OF Non-invasive investigations of a wall painting using optical coherence tomography and hyperspectral imaging (Invited Paper) [8084-14]

H. Liang, R. Lange, Nottingham Trent Univ. (United Kingdom); H. Howard, The National

Gallery (United Kingdom); J. Spooner, Historic Royal Palaces (United Kingdom)

8084 OG Application of optical coherence tomography (OCT) for real time monitoring of consolidation of the paint layer in Hinterglasmalerei objects [8084-15]

M. Iwanicka, E. A. Kwiatkowska, M. Sylwestrzak, P. Targowski, Nicolaus Copernicus Univ. (Poland)

$8084 \mathrm{OH}$ OCT and NMR for non-invasive in-situ monitoring of the vulnerability of rock art monuments [8084-16]

E. Bemand, M. Bencsik, H. Liang, Nottingham Trent Univ. (United Kingdom)

8084 Ol Shape-from-silhovette for three-dimensional reconstruction from $\mathrm{x}$-ray radiography [8084-17]

E. Simioni, F. Ratti, L. Poletto, Univ. degli Studi di Padova (Italy) 


\section{D TECHNIQUES}

8084 0J Preliminary investigation on monitoring transportation effects by full field methods: a digital holographic speckle pattern interferometry study on canvas paintings (Invited Paper) [8084-18]

E. Tsiranidou, E. Bernikola, V. Tornari, Foundation for Research and Technology-Hellas (Greece); T. Fankhauser, M. Läuchli, C. Palmbach, N. Bäschlin, Hochschule der Künste Bern (Switzerland)

8084 OK Infrared digital holography applications for virtual museums and diagnostics of cultural heritage [8084-19]

M. Paturzo, A. Pelagotti, A. Geltrude, M. Locatelli, P. Poggi, R. Meucci, P. Ferraro, Istituto Nazionale di Ottica, CNR (Italy); E. Stoykova, Institute of Optical Materials and Technologies (Bulgaria) and Bilkent Univ. (Turkey); F. Yaraş, A. Özgür Yontem, H. Kang,

L. Onural, Bilkent Univ. (Turkey)

$8084 \mathrm{OL}$ Application of digital image correlation (DIC) for tracking deformations of paintings on canvas [8084-20]

M. Malesa, K. Malowany, Warsaw Univ. of Technology (Poland); L. Tymińska-Widmer, E. A. Kwiatkowska, Nicolaus Copernicus Univ. (Poland); M. Kujawińska, Warsaw Univ. of Technology (Poland); B. J. Rouba, P. Targowski, Nicolaus Copernicus Univ. (Poland)

8084 OM Study on the currently accessible technology for 3D printing of color objects from the reproduction quality standpoint [8084-21]

R. Sitnik, G. Mączkowski, J. Krzesłowski, T. Gadzinski, Warsaw Univ. of Technology (Poland)

8084 ON S. Peter Martyr (Rieti, Italy): a study case for 3D color laser scanner (RGB-ITR) [8084-22] M. Guarneri, G. Fornetti, M. Ferri De Collibus, M. Francucci, R. Ricci, M. Nuvoli, Ente per le Nuove tecnologie, l'Energia e l'Ambiente (Italy)

\section{POSTER SESSION}

808400 Small-dimension portable instrument for in-situ multispectral imaging [8084-23]

A. Piegari, A. Sytchkova, Ente per le Nuove tecnologie, l'Energia e l'Ambiente (Italy); A. Della Patria, Istituto Nazionale di Ottica, CNR (Italy); F. Fermi, C. Oleari, Univ. degli Studi di Parma (Italy)

8084 OP Colour measurements of surfaces to evaluate the restoration materials [8084-24] A. Lo Monaco, M. Marabelli, C. Pelosi, R. Picchio, Univ. degli Studi della Tuscia (Italy)

8084 OR Importance of integrated results of different non-destructive techniques in order to evaluate defects in panel paintings: the contribution of infrared, optical and ultrasonic techniques [8084-27]

S. Sfarra, Univ. degli Studi dell'Aquila (Italy); P. Theodorakeas, National Technical Univ. of Athens (Greece); C. Ibarra-Castanedo, Univ. Laval (Canada); N. P. Avdelidis, National Technical Univ. of Athens (Greece); A. Paoletti, D. Paoletti, Univ. degli Studi dell'Aquila (Italy); K. Hrissagis, National Technical Univ. of Athens (Greece); A. Bendada, Univ. Laval (Canada); M. Koui, National Technical Univ. of Athens (Greece); X. Maldague, Univ. Laval (Canada) 
8084 OS Hylemetry versus Biometry: a new method to certificate the lithography authenticity [8084-28]

G. Schirripa Spagnolo, L. Cozzella, C. Simonetti, Univ. degli Studi di Roma Tre (Italy)

$8084 \mathrm{OU}$ Hand-held 3D sensor for documentation of fossil and archaeological excavations [8084-31] P. Kühmstedt, C. Bräuer-Burchardt, I. Schmidt, M. Heinze, A. Breitbarth, G. Notni, Fraunhofer-Institut für Angewandte Optik und Feinmechanik (Germany)

8084 OW IRIS: a novel spectral imaging system for the analysis of cultural heritage objects [8084-33] V. M. Papadakis, Y. Orphanos, S. Kogou, K. Melessanaki, P. Pouli, C. Fotakis, Foundation for Research and Technology-Hellas (Greece)

8084 OY Remote multispectral imaging with PRISMS and XRF analysis of Tang tomb paintings [8084-36]

R. Lange, Nottingham Trent Univ. (United Kingdom); Q. Zhang, Shaanxi History Museum (China); H. Liang, Nottingham Trent Univ. (United Kingdom)

Author Index 


\title{
Conference Committee
}

\author{
Symposium Chairs
}

Wolfgang Osten, Universität Stuttgart (Germany)

Małgorzata Kujawińska, Warsaw University of Technology (Poland)

Pietro Ferraro, Istituto Nazionale di Ottica Applicata, CNR (Italy)

Conference Chairs

Luca Pezzati, Istituto Nazionale di Ottica Applicata, CNR (Italy)

Renzo Salimbeni, Istituto di Fisica Applicata Nello Carrara (Italy)

Program Committee

John F. Asmus, University of California, San Diego (United States)

Brunetto G. Brunetti, Università degli Studi di Perugia (Italy)

Andreas Burmester, Doerner Institut (Germany)

Marta Castillejo, Consejo Superior de Investigaciones Científicas (Spain)

Alberto de Tagle, Netherlands Institute for Cultural Heritage (Netherlands)

John Delaney, National Gallery of Art (United States)

Mady Elias, Université Pierre et Marie Curie (France)

Raffaella E. M. Fontana, Istituto Nazionale di Ottica Applicata, CNR (Italy)

Igor P. Gurov, Saint-Petersburg State University of Information Technologies, Mechanics and Optics (Russian Federation)

Alexander J. Kossolapov, The Hermitage Museum (Russian Federation) Haida Liang, Nottingham Trent University (United Kingdom)

David R. Saunders, The British Museum (United Kingdom)

Piotr Targowski, Nicolaus Copernicus University (Poland)

Vivi Tornari, Foundation for Research and Technology-Hellas (Greece)

Session Chairs

Keynote Session

Luca Pezzati, Istituto Nazionale di Ottica, CNR (Italy)

1 Imaging and Spectral Methods I

Mady Elias, Université Pierre et Marie Curie (France)

2 Imaging and Spectral Methods II

Marta Castillejo, Consejo Superior de Investigaciones Científicas

(Spain) 
3 Imaging and Spectral Methods III

Marta Castillejo, Consejo Superior de Investigaciones Científicas

(Spain)

$4 \quad$ Data Processing

Haida Liang, Nottingham Trent University (United Kingdom)

5 Tomography

Vivi Tornari, Foundation for Research and Technology-Hellas (Greece)

6 3D Techniques

Raffaella E. M. Fontana, Istituto Nazionale di Ottica, CNR (Italy) 